\title{
Prenatal and Postnatal Cell Phone Exposures and Headaches in Children
}

\author{
Madhuri Sudan ${ }^{*}$, , Leeka Kheifets ${ }^{1}$, Onyebuchi Arah ${ }^{1,2}$, Jorn Olsen $^{1,3}$ and Lonnie Zeltzer ${ }^{4}$ \\ ${ }^{I}$ Department of Epidemiology, School of Public Health, University of California, Los Angeles, California, USA \\ ${ }^{2}$ Department of Public Health, Academic Medical Center, University of Amsterdam, Amsterdam, The Netherlands \\ ${ }^{3}$ Institute of Public Health, University of Aarhus, Aarhus, Denmark \\ ${ }^{4}$ David Geffen School of Medicine, University of California, Los Angeles, California, USA
}

\begin{abstract}
Objective: Children today are exposed to cell phones early in life, and may be at the greatest risk if exposure is harmful to health. We investigated associations between cell phone exposures and headaches in children.

Study Design: The Danish National Birth Cohort enrolled pregnant women between 1996 and 2002. When their children reached age seven years, mothers completed a questionnaire regarding the child's health, behaviors, and exposures. We used multivariable adjusted models to relate prenatal only, postnatal only, or both prenatal and postnatal cell phone exposure to whether the child had migraines and headache-related symptoms.

Results: Our analyses included data from 52,680 children. Children with cell phone exposure had higher odds of migraines and headache-related symptoms than children with no exposure. The odds ratio for migraines was $1.30(95 \%$ confidence interval: 1.01-1.68) and for headache-related symptoms was 1.32 (95\% confidence interval: 1.23-1.40) for children with both prenatal and postnatal exposure.

Conclusions: In this study, cell phone exposures were associated with headaches in children, but the associations may not be causal given the potential for uncontrolled confounding and misclassification in observational studies such as this. However, given the widespread use of cell phones, if a causal effect exists it would have great public health impact.
\end{abstract}

Keywords: Cellular phone, child, electromagnetic frequency, environmental exposure, migraine, mobile phone, pain, radiofrequency.

\section{INTRODUCTION}

Cell phone use has increased rapidly in recent years, with 5.2 billion cell phone subscribers at the end of $2010[1,2]$. This has led to concern about the potential health effects of exposure to radio frequency (RF) radiation from cell phones. Children today are exposed to cell phones at a very early age and continuing throughout life. They might therefore achieve a much higher lifetime exposure than today's adults. Children may also be more susceptible to potential effects of RF due to their developing organ and tissue systems [3]. With differences in the size, shape, water content, and tissue distribution of the head, brain tissue in children has a higher specific absorption rate of RF than in adults [4]. Should RF exposure from cell phones have a harmful effect on health, children may be at the highest risk and should be given high priority in research related to RF health effects [5].

A great deal of scientific and public interest has focused on outcomes of brain and neck cancer in relation to cell phone exposure, and the International Agency for Research on Cancer recently classified RF radiation as possibly carcinogenic [6]. However, laboratory, provocation, and

*Address correspondence to this author at the 650 Charles E. Young Drive South, 71-254 CHS, Los Angeles, CA 90095, USA; Fax: (310) 206-6039; E-mail:msudan@ucla.edu epidemiologic studies have reported a range of findings related to cell phone exposures across various non-cancer outcomes which may be more plausible [7-14], and a number of relevant outcomes are yet to be studied. As cell phones are typically positioned close to the head during conversations, there are concerns about their effect on the occurrence of non-cancer disorders of the brain such as headaches.

Headache is the most common type of pain reported by children, and prevalence and incidence of headaches in children may be increasing [15-17]. Previous reports have indicated that adults commonly report experiencing headache symptoms in relation to cell phone use [18-20]. Cross-sectional and provocation studies have looked into this issue among adults and children with mixed results, but are limited by methodology and sample size [21-26]. The present study investigated the associations between mothers' reports of prenatal and postnatal cell phone exposures and outcomes of migraines and other headache-related symptoms in seven year-old children.

\section{METHODS}

We used data from the Danish National Birth Cohort (DNBC), which enrolled 91,661 pregnant women in Denmark between 1996 and 2002. Approximately 50\% of all pregnant women in Denmark from 1996-2002 were invited to participate, and about $60 \%$ of those invited accepted the 
invitation. The women and the children born from their pregnancies have been followed since enrollment, and follow-up will continue for decades into the children's lifetimes. For each pregnancy, the DNBC collected detailed information on lifestyle and environmental exposures from interviews with the mothers at gestational weeks 12 and 30 and again when the children were six and 18 months of age [27].

When the children reached seven years of age, mothers were invited to complete a questionnaire that focused on the child's exposures, lifestyle, and health problems. Letters were sent to participants instructing them about how to use the Internet version or the paper-based mail-in version of the age-seven questionnaire. Women that did not respond within four weeks were sent a reminder by mail. Paper questionnaires were sent to women who still had not responded four weeks after the reminders were sent. The format and questions of the Internet and paper questionnaires were identical [13].

This study was approved by the Danish Data Protection Agency, regional science ethics committees in Denmark, and the Office for the Protection of Research Subjects at the University of California, Los Angeles. Women who participated in the DNBC gave written informed consent prior to inclusion in the cohort. Women who requested to discontinue participation at any time or whose child was deceased were not contacted for further follow-up.

The age-seven questionnaire included questions about whether or not the mother used a cell phone while she was pregnant with the index child (prenatal cell phone exposure) and her prenatal cell phone use behaviors (frequency of use, use of hands-free devices, percent of time the phone was powered on, and location of the phone when not in use). Mothers were also asked whether or not her child uses a cell phone (postnatal cell phone exposure). The prenatal and postnatal exposure variables were coded into four exposure categories. Thus, each child was categorized as having prenatal only, postnatal only, both prenatal and postnatal, or no exposure.

Our outcomes of interest were based on mothers' reports in the age-seven questionnaire. Mothers reported whether or not their child suffers from migraines. They also responded to the statement "often complains of headaches, stomach aches, or sickness" about their child on a three-point scale (1=not true, 2=partly true, $3=$ very true) in the Strengths and Difficulties Questionnaire module of the age-seven questionnaire. Reports of "partly true" and "very true" were coded $1=$ yes, and reports of "not true" were coded $0=$ no for headache-related symptoms.

We also linked mothers and children to various social and medical population-based registers. We obtained mothers' records of migraine diagnoses during hospital admissions, emergency room visits, and visits to specialty outpatient clinics from the Danish National Hospital Register. Diagnoses were recorded using International Classification of Diseases, 8th Revision criteria between 1977 and 1996 and using International Classification of Diseases, $10^{\text {th }}$ Revision criteria from 1996 onwards. Birth data for the children were obtained from the Danish Medical
Birth Registry. Social-occupational status was based on both parents' education, income, and job status information collected during the 12-week prenatal interview.

We used logistic regression models to compute odds ratios (OR) and 95\% confidence intervals (CI) for the associations between mothers' reports of outcomes in children and prenatal only, postnatal only, and both prenatal and postnatal exposure compared to children with no exposure. We considered several potential confounders for adjustment, and based on prior knowledge from the literature, statistical adjustments were made for mother's age, mother's history of migraines, mother's feelings of worry, burden, and stress during pregnancy, socialoccupational status, child's exposure to tobacco smoke, and child's sex. Complete-case analyses were used in developing our logistic regression models, and children classified as having "unknown exposure" due to missing information about either prenatal or postnatal exposure were not included in these models. To account for possible bias introduced by missing data, we performed multiple imputation of the dataset assuming data were missing at random (conditional on observed data). The results of the logistic regression models after multiple imputation were materially the same as those prior to multiple imputation, and the amount of missing data was small.

We considered proxies for prenatal exposure to evaluate the possibility of an exposure-response. These included the number of times per day the mother reported speaking on her cell phone, percent of time the cell phone was powered on, and location where the mother carried her phone when it was not in use. Mother's use of a hands-free device was also included, as we would expect using a hands-free device to lower exposure to the mother, but potentially increase exposure to the fetus if the phone is placed in a pocket, bag, or near the abdomen while in use. We used logistic regression models to estimate the odds of migraine and other headache-related symptoms by each proxy for prenatal exposure.

All statistical analyses were conducted in SAS version 9.2 (SAS Institute Inc., Cary, North Carolina, USA).

\section{RESULTS}

These analyses are based on data from 52,680 children from singleton births whose mothers responded to the ageseven DNBC questionnaire. Of the 91,256 mothers that were invited to participate in the age-seven interview, a total of 59,975 completed and submitted the questionnaire $(66 \%$ participation rate). Children from multiple births (twins, triplets, and so on) were not included in this analysis, and data from the most recently completed questionnaires (after April 2010) were not available at the time of this study. According to mothers' reports, $39 \%$ percent of children were exposed prenatally $(n=20,482)$, and $36 \%$ percent used a cell phone at age seven years $(n=18,935)$, but less than $1 \%$ used it more than one hour per week. Twenty percent of children were exposed prenatally only, $16 \%$ postnatally only, $19 \%$ both prenatally and postnatally, and $40 \%$ had no reported cell phone exposure (Table 1). Five percent of children were classified as having unknown exposure because they were missing data on either prenatal or postnatal exposure. 
Table 1. Distribution of Sample Characteristics by Mother's Report of Cell Phone Exposure

\begin{tabular}{|c|c|c|c|c|c|c|c|c|c|c|c|c|}
\hline & \multicolumn{2}{|c|}{$\begin{array}{c}\text { No Exposure } \\
(n=\mathbf{2 1 , 5 0 7 )}\end{array}$} & \multicolumn{2}{|c|}{$\begin{array}{c}\text { Prenatal } \\
\text { Exposure Only } \\
(n=10,690)\end{array}$} & \multicolumn{2}{|c|}{$\begin{array}{c}\text { Postnatal } \\
\text { Exposure Only }^{\mathrm{b}} \\
(\boldsymbol{n}=\mathbf{8 , 2 1 3})\end{array}$} & \multicolumn{2}{|c|}{$\begin{array}{l}\text { Both Prenatal } \\
\text { and Postnatal } \\
\text { Exposure }^{\mathrm{a}, \mathrm{b}} \\
(n=9,781)\end{array}$} & \multicolumn{2}{|c|}{$\begin{array}{c}\text { Unknown } \\
\text { Exposure } \\
(n=2,489)\end{array}$} & \multicolumn{2}{|c|}{$\begin{array}{c}\text { Total } \\
(n=52,680)\end{array}$} \\
\hline & $n$ & $\%$ & $n$ & $\%$ & $n$ & $\%$ & $n$ & $\%$ & $n$ & $\%$ & $n$ & $\%$ \\
\hline $\begin{array}{l}\text { Sex of child } \\
\text { Boy } \\
\text { Girl } \\
\end{array}$ & $\begin{array}{l}11,431 \\
10,076\end{array}$ & $\begin{array}{l}53.2 \\
46.8 \\
\end{array}$ & $\begin{array}{l}5,821 \\
4,869 \\
\end{array}$ & $\begin{array}{l}54.5 \\
45.5 \\
\end{array}$ & $\begin{array}{l}3,799 \\
4,414 \\
\end{array}$ & $\begin{array}{l}46.3 \\
53.7 \\
\end{array}$ & $\begin{array}{l}4,596 \\
5,185 \\
\end{array}$ & $\begin{array}{l}47.0 \\
53.0\end{array}$ & $\begin{array}{l}1,341 \\
1,148 \\
\end{array}$ & $\begin{array}{l}53.9 \\
46.1 \\
\end{array}$ & $\begin{array}{l}26,988 \\
25,692 \\
\end{array}$ & $\begin{array}{l}51.2 \\
48.8 \\
\end{array}$ \\
\hline $\begin{array}{l}\text { Child exposed to tobacco } \\
\text { smoke in home } \\
\text { Often or daily } \\
\text { Rarely } \\
\text { Never } \\
\text { Missing } \\
\end{array}$ & $\begin{array}{r}1,513 \\
5,054 \\
14,899 \\
41 \\
\end{array}$ & $\begin{array}{r}7.0 \\
23.5 \\
69.3 \\
0.2 \\
\end{array}$ & $\begin{array}{r}876 \\
2,135 \\
7,658 \\
21 \\
\end{array}$ & $\begin{array}{r}8.2 \\
20.0 \\
71.6 \\
0.2 \\
\end{array}$ & $\begin{array}{r}830 \\
2,188 \\
5,182 \\
13 \\
\end{array}$ & $\begin{array}{r}10.1 \\
26.6 \\
63.1 \\
0.2 \\
\end{array}$ & $\begin{array}{r}1,241 \\
2,361 \\
6,155 \\
24 \\
\end{array}$ & $\begin{array}{r}12.7 \\
24.1 \\
62.9 \\
0.3 \\
\end{array}$ & $\begin{array}{r}204 \\
590 \\
1,528 \\
167 \\
\end{array}$ & $\begin{array}{r}8.2 \\
23.7 \\
61.4 \\
6.7 \\
\end{array}$ & $\begin{array}{r}4,664 \\
12,328 \\
35,422 \\
266 \\
\end{array}$ & $\begin{array}{r}8.9 \\
23.4 \\
67.2 \\
0.5 \\
\end{array}$ \\
\hline $\begin{array}{l}\text { Mother diagnosed with } \\
\text { migraine (hospital register) } \\
\text { Yes } \\
\text { No }\end{array}$ & $\begin{array}{r}330 \\
21,177 \\
\end{array}$ & $\begin{array}{r}1.5 \\
98.5 \\
\end{array}$ & $\begin{array}{r}235 \\
10,455 \\
\end{array}$ & $\begin{array}{r}2.2 \\
97.8 \\
\end{array}$ & $\begin{array}{r}169 \\
8,044 \\
\end{array}$ & $\begin{array}{r}2.1 \\
97.9 \\
\end{array}$ & $\begin{array}{r}220 \\
9,561 \\
\end{array}$ & $\begin{array}{r}2.2 \\
97.8 \\
\end{array}$ & $\begin{array}{r}37 \\
2,452 \\
\end{array}$ & $\begin{array}{r}1.5 \\
98.5 \\
\end{array}$ & $\begin{array}{r}991 \\
51,689 \\
\end{array}$ & $\begin{array}{r}1.9 \\
98.1 \\
\end{array}$ \\
\hline $\begin{array}{l}\text { Mother's feelings of stress, } \\
\text { worry, or burden during } \\
\text { pregnancy }(0-54) \\
\text { Mean (SD) } \\
\end{array}$ & & (3.6) & & $(3.7)$ & & (3.9) & & 4.14) & & $(4.0)$ & & $(3.8)$ \\
\hline $\begin{array}{l}\text { Child gets migraines } \\
\text { (mother's report) } \\
\text { Yes } \\
\text { No } \\
\text { Missing }\end{array}$ & $\begin{array}{r}176 \\
20,993 \\
338 \\
\end{array}$ & $\begin{array}{r}0.8 \\
97.6 \\
1.6\end{array}$ & $\begin{array}{r}116 \\
10,398 \\
176 \\
\end{array}$ & $\begin{array}{r}1.1 \\
97.3 \\
1.6\end{array}$ & $\begin{array}{r}89 \\
7,989 \\
135 \\
\end{array}$ & $\begin{array}{r}1.1 \\
97.3 \\
1.6 \\
\end{array}$ & $\begin{array}{r}120 \\
9,472 \\
189 \\
\end{array}$ & $\begin{array}{r}1.2 \\
96.8 \\
1.9 \\
\end{array}$ & $\begin{array}{r}22 \\
2,349 \\
118 \\
\end{array}$ & $\begin{array}{r}0.9 \\
94.4 \\
4.7 \\
\end{array}$ & $\begin{array}{r}523 \\
51,201 \\
956 \\
\end{array}$ & $\begin{array}{r}1.0 \\
97.2 \\
1.8 \\
\end{array}$ \\
\hline
\end{tabular}

${ }^{\mathrm{a}}$ Mother reported using cell phone while pregnant.

${ }^{b}$ Mother reported child uses cell phone at age seven years.

Children with both prenatal and postnatal exposure to cell phones had the highest ORs for migraines and other headache-related symptoms compared to children with no exposure (Table 2). For these children, the adjusted ORs were 1.30 (95\% CI: 1.01-1.68) for migraine, and $1.32(95 \%$ CI: 1.23-1.40) for other headache-related symptoms. Since parents sometimes call all headaches in children "migraines", we repeated this analysis after collapsing the

Table 2. Odds Ratios for Migraines and Other Headache-Related Symptoms in Children According to Mother's Report of Cell Phone Exposure

\begin{tabular}{|l|c|c|c|}
\hline & $\begin{array}{c}\text { Prenatal Exposure Only } \\
(\mathbf{n = 1 0 , 6 9 0 )}\end{array}$ & $\begin{array}{c}\text { Postnatal Exposure Only } \\
(\boldsymbol{n}=\mathbf{8 , 2 1 3})\end{array}$ & $\begin{array}{c}\text { Both Prenatal and Postnatal } \\
\text { Exposure } \\
(\boldsymbol{n}=\mathbf{9 , 7 8 1})\end{array}$ \\
\hline \hline $\begin{array}{c}\text { Child gets migraines } \\
\text { OR }(95 \% \mathrm{CI})\end{array}$ & $1.33(1.05-1.68)$ & $1.33(1.03-1.72)$ & $1.51(1.20-1.91)$ \\
$\mathrm{OR}^{\mathrm{a}, \mathrm{b}}(95 \% \mathrm{CI})$ & $1.20(0.93-1.54)$ & $1.21(0.92-1.60)$ & $1.30(1.01-1.68)$ \\
\hline $\mathrm{Child}^{\mathrm{a}}$ has headache-related symptoms & $1.19(1.12-1.26)$ & $1.36(1.28-1.45)$ & $1.51(1.42-1.60)$ \\
$\mathrm{OR}^{\mathrm{a}}(95 \% \mathrm{CI})$ & $1.16(1.08-1.23)$ & $1.28(1.19-1.37)$ & $1.32(1.23-1.40)$ \\
$\mathrm{OR}^{\mathrm{a}, \mathrm{b}}(95 \% \mathrm{CI})$ & & \\
\hline
\end{tabular}

${ }^{\mathrm{a}}$ Reference category is no exposure to cell phones.

${ }^{b}$ Adjusted for child's sex, mother diagnosed with migraines, mother's feelings of worry, burden, and stress during pregnancy, mother's age, social-occupational status, and child's exposure to environmental tobacco smoke in the home. 
Table 3. Odds Ratios for Migraines and Headache-Related Symptoms in Children According to Mother's Report of Cell Phone Use Characteristics During Pregnancy

\begin{tabular}{|c|c|c|c|c|c|c|c|c|c|c|}
\hline & \multirow[b]{2}{*}{$n$} & \multirow[b]{2}{*}{$\%^{a}$} & \multicolumn{4}{|c|}{$\begin{array}{l}\text { Child gets Migraines } \\
\qquad(n=523)\end{array}$} & \multicolumn{4}{|c|}{$\begin{array}{l}\text { Child has Headache-Related } \\
\text { Symptoms } \\
(n=10,043)\end{array}$} \\
\hline & & & $\mathbf{O R}^{\mathrm{b}}$ & $95 \%$ CI & $\mathrm{OR}_{\mathrm{adj}}^{\mathrm{b}, \mathrm{c}}$ & $95 \%$ CI & $\mathbf{O R}^{\mathrm{b}}$ & $95 \%$ CI & $\mathbf{O R}_{\mathrm{adj}}^{\mathrm{b}, \mathrm{c}}$ & $95 \%$ CI \\
\hline $\begin{array}{l}\text { Use of hands-free device } \\
\text { No exposure (reference) } \\
\text { Never used hands-free device } \\
\text { Rarely used hands-free device } \\
\text { Often used hands-free device } \\
\text { Missing } \\
P \text { value for trend } \\
\end{array}$ & $\begin{array}{c}21,507 \\
16,205 \\
2,439 \\
1,745 \\
93\end{array}$ & $\begin{array}{l}79.1 \\
11.9 \\
8.5 \\
0.5\end{array}$ & $\begin{array}{l}1.00 \\
1.32 \\
1.77 \\
1.83 \\
\\
0.69\end{array}$ & $\begin{array}{l}1.07-1.63 \\
1.23-2.55 \\
1.21-2.77\end{array}$ & $\begin{array}{l}1.00 \\
1.11 \\
1.51 \\
1.82 \\
\\
0.69\end{array}$ & $\begin{array}{l}0.85-1.44 \\
0.98-2.30 \\
1.15-2.90\end{array}$ & $\begin{array}{l}1.00 \\
1.35 \\
1.34 \\
1.26 \\
\end{array}$ & $\begin{array}{l}1.28-1.42 \\
1.21-1.49 \\
1.11-1.42\end{array}$ & $\begin{array}{l}1.00 \\
1.15 \\
1.12 \\
1.12 \\
\\
0.01\end{array}$ & $\begin{array}{l}1.08-1.23 \\
0.99-1.26 \\
0.97-1.29\end{array}$ \\
\hline $\begin{array}{l}\text { Frequency of cell phone use } \\
\text { No exposure (reference) } \\
0-1 \text { times per day } \\
2-3 \text { times per day } \\
4-6 \text { times per day } \\
7 \text { or more times per day } \\
\text { Missing } \\
P \text { value for trend } \\
\end{array}$ & $\begin{array}{c}21,507 \\
10,339 \\
5,699 \\
1,430 \\
830 \\
2,184\end{array}$ & $\begin{array}{c}50.5 \\
27.8 \\
7.0 \\
4.1 \\
10.7\end{array}$ & $\begin{array}{l}1.00 \\
1.44 \\
1.07 \\
1.81 \\
2.08 \\
\\
0.05 \\
\end{array}$ & $\begin{array}{l}1.14-1.82 \\
0.78-1.47 \\
1.15-2.86 \\
1.20-3.60\end{array}$ & $\begin{array}{l}1.00 \\
1.26 \\
0.82 \\
1.47 \\
1.89 \\
\\
0.03 \\
\end{array}$ & $\begin{array}{l}0.95-1.67 \\
0.56-1.21 \\
0.87-2.50 \\
1.03-3.45\end{array}$ & $\begin{array}{l}1.00 \\
1.30 \\
1.33 \\
1.39 \\
1.45 \\
<0.01 \\
\end{array}$ & $\begin{array}{l}1.22-1.38 \\
1.24-1.44 \\
1.22-1.59 \\
1.23-1.72\end{array}$ & $\begin{array}{l}1.00 \\
1.16 \\
1.10 \\
1.14 \\
1.26 \\
\\
0.03 \\
\end{array}$ & $\begin{array}{l}1.08-1.24 \\
1.01-1.21 \\
0.98-1.32 \\
1.04-1.52\end{array}$ \\
\hline
\end{tabular}

${ }^{\text {a}}$ Percent among those with prenatal exposure.

${ }^{\mathrm{b}}$ Reference category is no cell phone exposure.

${ }^{c}$ Estimates adjusted for mother's age, socio-occupational status, mother's history of migraine headaches, mother's feelings of worry, burden, and stress during pregnancy, child's exposure to environmental tobacco smoke, and postnatal exposure.

${ }^{\mathrm{d}} P$ value from Wald $\chi^{2}$ test for linear trend. $P$ value $>0.05$ suggests a linear trend at $95 \%$ confidence.

two outcomes into one variable, and observed similar results (data not shown). Children with prenatal or postnatal exposure only also had increased odds of headache-related symptoms compared to children with no exposure. The ORs were 1.16 (95\% CI: 1.08-1.23) for prenatal exposure only and 1.28 (95\% CI: 1.19-1.37) for postnatal exposure only. The ORs for migraine were also elevated among children with prenatal only or postnatal only exposure, but not statistically significant.

Eighty-five percent of women carried their cell phones in their bag when not in use, while only seven percent reported keeping it in the pocket of their dress or trousers (pants) while pregnant (data not shown). Seventy-nine percent of women that used a cell phone while pregnant did not use a hands-free device, less than half reported using their cell phone more than once per day, and over $80 \%$ left it powered on at least $50 \%$ of the time (Table 3 ). When comparing the children of women who used a cell phone while pregnant to those children with no exposure, those with potentially higher prenatal exposure had increased odds of migraines and other headache-related symptoms.

\section{DISCUSSION}

In this investigation, we found associations between prenatal and postnatal cell phone exposures and outcomes of migraines and headache-related symptoms in children, but our results should be interpreted with caution due to limitations in exposure and outcome assessment. However, this is the first large-scale study among children to investigate this association, and it supports the previous smaller investigations in children and adults that reported positive findings $[21,23,26]$. Given the high prevalence of cell phone exposure, increasing use at earlier ages, and potential increases in prevalence and incidence of headache in children over time [15-17], our results highlight a need for additional research on headaches and other non-cancer outcomes, including more large-scale studies among children.

We did not use migraine and other headache diagnoses among children from the hospital register to calculate measures of association due to the limited number of recorded cases. Only 64 migraine cases and 34 cases of other headache were recorded in the hospital register, compared to 523 cases of migraine and 10,043 cases of headache/stomach ache/illness reported by mothers in the questionnaire. Migraine and headache diagnoses in children are likely to be made by general practitioners during primary care visits rather than during specialty care or hospital visits. Therefore, very few childhood migraine and headache diagnoses are recorded in the hospital register. Those that are recorded are likely to be very severe cases, headaches in combination with co-morbidities, or headaches that do not respond to standard treatments.

We found fewer cases of childhood migraine according mothers' reports in our data than expected from previous prevalence estimates [28-30]. Migraines in children often present with different symptoms than adult migraines and may go unrecognized by both health practitioners and 
parents [31-33]. Further, prevalence of migraines and other headaches increase with age in children [34]. Therefore, outcomes measured at age seven years may not fully reflect the potential impact of early RF exposure on occurrence of migraines and headaches, which are more prevalent later in childhood and adolescence.

The DNBC age-seven questionnaire did not collect information about non-migraine headaches or other migraine symptoms in children directly. Rather, mothers were asked about their children's complaints of "headaches, stomach aches, and sickness". This non-specific outcome measure may represent overall well-being and may capture children who experience non-migraine headaches and migraines that present without headache symptoms. Should headacherelated effects of RF exposures exist, these effects could possibly be involved in activating central pain signaling mechanisms in the brain related to broader pain symptoms, rather than headaches alone. The observed associations between cell phone exposures and headaches, stomach aches, and sickness may reflect this hypothetical effect. On the other hand, this outcome may also represent greater somatization in some children, thus serving as a proxy for other factors such as stress, depression, or anxiety [35].

Exposure assessment in this study was limited to mothers' reports of prenatal cell phone use and their children's cell phone use at age seven years. Although actual RF exposure was not measured, exposure to the fetus from maternal cell phone use during pregnancy is likely to be low $[36,37]$. Further, most children were not using cell phones at age seven, and those who were did so for short periods of time. Thus, children's overall exposure to RF from cell phones was most likely low. Therefore, the association we found could be the result of underlying factors associated with cell phone use rather than a direct effect of RF exposure.

We found associations between proxies of prenatal exposure and headaches in children. Number of times spoken on a cell phone per day and percentage of time the cell phone was powered on during pregnancy were both positively associated with migraines in children at age seven compared to no exposure. We also found that greater use of a hands-free device during pregnancy was associated with increased odds of migraines in children. We expect that, while a mother's use of a hands-free device during phone conversations lowered the RF exposure to her head [38], exposure to the fetus may have been increased, especially if the mother carried her cell phone close to her abdomen.

We recognize the potential for exposure misclassification in this study, but we do not expect it to have produced these results. Assessment of cell phone use during pregnancy was done retrospectively after seven years and may be subject to recall error. However, pregnancy leaves a strong impression on women's memories, and they tend to remember their behaviors during this unique time with high accuracy [39, 40]. We expect the mothers in this study to have been able to accurately recall whether or not they used a cell phone during pregnancy, while specific prenatal cell phone use behaviors such as frequency of use are more likely to serve as rough proxies of exposure. Assessment of the child's exposure was very general (whether the child uses a cell phone more or less than one hour per week or not at all); mothers should have been able to answer the question accurately.

Outcome misclassification in this study might be a concern. However, at the time of the age-seven interview, no studies had been done to cause mothers to believe that cell phone exposure was associated with the study outcomes. The data collection instrument included many questions on a wide range of outcomes and exposures, and questions about migraines and headaches were asked separately from questions about cell phone use. Although we do not expect outcome misclassification to be directly associated with cell phone exposure, we cannot rule out that the propensity for some mothers to over- or under-report outcomes may be associated with underlying factors that are also related to cell phone exposure, or more generally, to cell phone usage patterns.

Selection bias is unlikely to account for the associations we detected. Denmark has a relatively homogenous population with nearly universal access to and utilization of prenatal and other medical care. Additionally, both diseases and outcomes of interest occurred after enrollment. Therefore, women who chose not to participate in the study are unlikely to be different from participants on factors that could introduce bias into our results. Although a large proportion of the original study participants were not included in our analysis due to non-response during ageseven data collection, we do not expect the loss-to-follow-up to be differential. We have no reason to believe that migraine and headache outcomes are associated with participation or inclusion.

A recent study estimating loss-to-follow-up bias in the DNBC found that mothers who were lost-to-follow-up were more likely to be in the low social-occupational status category than women who continued participation [41]. Several studies have reported that cell phone use among children and adolescents is inversely associated with socialoccupational status [42-46]. Therefore, it is possible that children (and possibly mothers) who are heavier cell phone users may have been less likely to continue follow-up in the DNBC, and therefore are under-represented in our data. As social-occupational status may be inversely associated with headaches in children [47], this loss-to-follow-up could have downwardly biased our results.

A major strength of this study is the large number of both exposed and unexposed children in our sample. During the time that women in this study were pregnant, cell phone use was still gaining popularity, leaving a large proportion of the children prenatally unexposed. Another advantage is the large sample size with good exposure contrast and rich covariate data from a well-published prospective cohort. A study like this would be difficult to repeat today, as very few non-exposed individuals remain.

Using data from the DNBC offers many additional advantages. With long-term follow-up of the children and linkage to population registers we were able to measure and control for a large number of prenatal and postnatal variables in our analysis. Further, there is less likelihood for confounding by factors such as ethnic background, socioeconomic status, and access to healthcare in data from Denmark than studies conducted in many other countries. 
We ran numerous models with both univariate and multivariate adjustment for a large number of variables. While as expected, adjusting for a large number of factors resulted in reduced ORs, the associations remained, and the results did not materially change. Additionally, results did not change after multiple imputation for missing data. Despite adjusting for a wide range of factors, other factors such as watching television, playing video games, and use of computers could be potential confounders and contributed to our observed results, but these factors were not measured in the age-seven DNBC questionnaire.

As the DNBC is an ongoing study, follow-up of children and mothers is planned to continue for several years to come. This will allow for longitudinal analyses of the association between cell phone exposures and headache outcomes among the children at later ages, when headaches are likely to be more prevalent. The impact of early RF exposure might manifest later during adolescence when executive function and other higher order brain functions develop. The latest wave of data collection is currently underway, with questionnaires to be completed by mothers and their children at the age of 11 years, and including more detailed exposure assessment questions. As the latest DNBC data become available, we hope to investigate this association further with a longitudinal analysis.

To our knowledge this is the first epidemiologic study to investigate the association between prenatal and postnatal cell phone exposures and migraines and other headacherelated symptoms in a large sample of children. The associations we found are not sufficient to conclude that cell phone exposures have an effect on headaches in children, but our results do demonstrate a need to investigate this association further with detailed exposure and outcome assessment in a large sample. Should a true causal effect exist, it would have large public health implications because cell phone exposure is nearly ubiquitous and children are using this technology at younger ages than ever before.

\section{CONFLICT OF INTEREST}

The authors confirm that this article content has no conflict of interest.

\section{ACKNOWLEDGEMENTS}

The authors would like to thank the coordinator of data collection, Inge Kristine Meder, data analysts, Inge Eisensee and Lone Fredslund Møller, and the participating mothers.

\section{FINANCIAL DISCLOSURE}

This work was supported by the Lundbeck Foundation [grant number 195/04]; the Danish Medical Research Council [grant number SSVF 0646]; the National Institutes of Health/National Institute of Environmental Health Sciences [grant number R21ES016831]; and a Veni career grant from the Netherlands Organization for Scientific Research (NWO) to OAA [grant number 916.96.059].

\section{REFERENCES}

[1] International Telecommunication Union. ITU sees 5 billion mobile subscriptions globally in 2010. 2010 [cited 2010 February 24]; Available from: http://www.itu.int/net/pressoffice/press_releases/2 010/06.aspx
[2] International Telecommunication Union. Global mobile cellular subscriptions, total and per 100 inhabitants, 2000-2010. 2011 [cited 2011 August 08]; Available from: http://www.itu.int/ITU-D/ict /statistics/material/excel/2010/Global mobile cellular 00-10.xls

[3] Kheifets L, Repacholi M, Saunders R, et al. The sensitivity of children to electromagnetic fields. Pediatrics 2005; 116: e303-13.

[4] Wiart J, Hadjem A, Wong MF, et al. Analysis of RF exposure in the head tissues of children and adults. Phys Med Biol 2008; 53: 3681-95.

[5] World Health Organization. WHO Research Agenda for Radiofrequency Fields. Geneva, Switzerland: 2010 [cited 2010 October 22]; Available from: http://whqlibdoc.who.int/publicati ons/2010/9789241599948_eng.pdf

[6] Baan R, Grosse Y, Lauby-Secretan B, et al. Carcinogenicity of radiofrequency electromagnetic fields. Lancet Oncol 2011; 12: 624-6.

[7] Volkow ND, Tomasi D, Wang GJ, et al. Effects of cell phone radiofrequency signal exposure on brain glucose metabolism. JAMA 2011; 305: 808-13

[8] van Rongen E, Croft R, Juutilainen J, et al. Effects of radiofrequency electromagnetic fields on the human nervous system. J Toxicol Environ Health B Crit Rev 2009; 12: 572-97.

[9] Oktay MF, Dasdag S. Effects of intensive and moderate cellular phone use on hearing function. Electromagn Biol Med 2006; 25: 13-21.

[10] Davidson HC, Lutman ME. Survey of mobile phone use and their chronic effects on the hearing of a student population. Int J Audiol 2007; 46: 113-8

[11] García Callejo FJ, García Callejo F, Peña Santamaría J, et al. Hearing level and intensive use of mobile phones. Acta Otorrinolaringol Esp 2005; 56: 187-91.

[12] Thomas S, Heinrich S, von Kries R, et al. Exposure to radiofrequency electromagnetic fields and behavioural problems in Bavarian children and adolescents. Eur J Epidemiol 2010; 25: 13541.

[13] Divan HA, Kheifets L, Obel C, et al. Prenatal and postnatal exposure to cell phone use and behavioral problems in children. Epidemiology 2008; 19: 523-9.

[14] Divan HA, Kheifets L, Obel C, et al. Cell phone use and behavioural problems in young children. J Epidemiol Commun Health 2012; 66: 524-9.

[15] Sillanpaa M, Anttila P. Increasing prevalence of headache in 7year-old schoolchildren. Headache 1996; 36: 466-70.

[16] Anttila P, Metsahonkala L, Sillanpaa M. Long-term trends in the incidence of headache in Finnish schoolchildren. Pediatrics 2006; 117: e1197-201.

[17] Rozen TD, Swanson JW, Stang PE, et al. Increasing incidence of medically recognized migraine headache in a United States population. Neurology 1999; 53: 1468-73.

[18] Oftedal G, Wilen J, Sandstrom M, et al. Symptoms experienced in connection with mobile phone use. Occup Med (Lond) 2000; 50: 237-45.

[19] Hocking B. Preliminary report: symptoms associated with mobile phone use. Occup Med (Lond) 1998; 48: 357-60.

[20] Frey AH. Headaches from cellular telephones: are they real and what are the implications? Environ Health Perspect 1998; 106: 101-3.

[21] Hillert L, Akerstedt T, Lowden A, et al. The effects of $884 \mathrm{MHz}$ GSM wireless communication signals on headache and other symptoms: an experimental provocation study. Bioelectromagnetics 2008; 29: 185-96.

[22] Milde-Busch A, von Kries R, Thomas S, et al. The association between use of electronic media and prevalence of headache in adolescents: results from a population-based cross-sectional study. BMC Neurol 2010; 10: 12.

[23] Heinrich S, Thomas S, Heumann C, et al. Association between exposure to radiofrequency electromagnetic fields assessed by dosimetry and acute symptoms in children and adolescents: a population based cross-sectional study. Environ Health 2010; 9: 75.

[24] Oftedal G, Straume A, Johnsson A, et al. Mobile phone headache: a double blind, sham-controlled provocation study. Cephalalgia 2007; 27: 447-55.

[25] Thomas S, Kuhnlein A, Heinrich S, et al. Personal exposure to mobile phone frequencies and well-being in adults: a crosssectional study based on dosimetry. Bioelectromagnetics 2008; 29: 463-70. 
[26] Soderqvist F, Carlberg M, Hardell L. Use of wireless telephones and self-reported health symptoms: a population-based study among Swedish adolescents aged 15-19 years. Environ Health 2008; 7: 18 .

[27] Olsen J, Melbye M, Olsen SF, et al. The Danish National Birth Cohort-its background, structure and aim. Scand J Public Health 2001; 29: 300-7.

[28] Raieli V, Raimondo D, Cammalleri R, et al. Migraine headaches in adolescents: a student population-based study in Monreale. Cephalalgia 1995; 15: 5-12; discussion 4.

[29] Abu-Arefeh I, Russell G. Prevalence of headache and migraine in schoolchildren. BMJ 1994; 309: 765-9.

[30] Sillanpaa M. Changes in the prevalence of migraine and other headaches during the first seven school years. Headache 1983; 23: 15-9.

[31] Igarashi M, May WN, Golden GS. Pharmacologic treatment of childhood migraine. J Pediatr 1992; 120: 653-7.

[32] MacDonald JT. Childhood migraine. Differential diagnosis and treatment. Postgrad Med 1986; 80: 301-4, 6.

[33] Winner P. How do we diagnose migraine and childhood periodic syndromes? Curr Pain Headache Rep 2005; 9: 345-50.

[34] King S, Chambers CT, Huguet A, et al. The epidemiology of chronic pain in children and adolescents revisited: A systematic review. Pain 2011; 152: 2729-38.

[35] Silber TJ. Somatization disorders: diagnosis, treatment, and prognosis. Pediatr Rev 2011; 32: 56-63; quiz 63-4.

[36] Dimbylow PJ, Nagaoka T, Xu XG. A comparison of foetal SAR in three sets of pregnant female models. Phys Med Biol 2009; 54: 2755-67.

[37] Nagaoka T, Saito K, Takahashi M, et al. Anatomically realistic reference models of pregnant women for gestation ages of 13, 18, and 26 weeks. Conf Proc IEEE Eng Med Biol Soc 2008; 2008: 2817-20.
[38] Kuhn S, Cabot E, Christ A, et al. Assessment of the radiofrequency electromagnetic fields induced in the human body from mobile phones used with hands-free kits. Phys Med Biol 2009; 54: 5493-508.

[39] Rice F, Lewis A, Harold G, et al. Agreement between maternal report and antenatal records for a range of pre and peri-natal factors: the influence of maternal and child characteristics. Early Hum Dev 2007; 83: 497-504.

[40] Hensley Alford SM, Lappin RE, Peterson L, et al. Pregnancy associated smoking behavior and six year postpartum recall. Matern Child Health J 2009; 13: 865-72.

[41] Greene N, Greenland S, Olsen J, et al. Estimating bias from loss to follow-up in the Danish National Birth Cohort. Epidemiology 2011; 22: 815-22.

[42] Mezei G, Benyi M, Muller A. Mobile phone ownership and use among school children in three Hungarian cities. Bioelectromagnetics 2007; 28: 309-15.

[43] Koivusilta LK, Lintonen TP, Rimpela AH. Orientations in adolescent use of information and communication technology: a digital divide by sociodemographic background, educational career, and health. Scand J Public Health 2007; 35: 95-103.

[44] Bohler E, Schuz J. Cellular telephone use among primary school children in Germany. Eur J Epidemiol 2004; 19: 1043-50.

[45] Soderqvist F, Hardell L, Carlberg M, et al. Ownership and use of wireless telephones: a population-based study of Swedish children aged 7-14 years. BMC Public Health 2007; 7: 105.

[46] Thomas S, Heinrich S, Kuhnlein A, et al. The association between socioeconomic status and exposure to mobile telecommunication networks in children and adolescents. Bioelectromagnetics 2010; 31: 20-7.

[47] Lateef TM, Merikangas KR, He J, et al. Headache in a national sample of American children: prevalence and comorbidity. J Child Neurol 2009; 24: 536-43.

(c) Sudan et al.; Licensee Bentham Open.

This is an open access article licensed under the terms of the Creative Commons Attribution Non-Commercial License (http://creativecommons.org/licenses/by$\mathrm{nc} / 3.0 /$ ) which permits unrestricted, non-commercial use, distribution and reproduction in any medium, provided the work is properly cited. 